Saudi Journal of Biomedical Research

Abbreviated Key Title: Saudi J Biomed Res ISSN 2518-3214 (Print) |ISSN 2518-3222 (Online)

Scholars Middle East Publishers, Dubai, United Arab Emirates Journal homepage: https://saudijournals.com/sjbr

Short Communication

\title{
Behaviors and Believes Against Coronavirus
}

Mosab Nouraldein Mohammed Hamad*

Head of Medical Parasitology Phylum, Faculty of Health Science, Elsheikh Abdallah Elbadri University, Sudan

DOI: $10.36348 /$ sjbr.2020.v05i03.002

| Received: 23.02.2020 | Accepted: 01.03.2020 | Published: 06.03.2020

*Corresponding author: Mosab Nouraldein Mohammed Hamad

Copyright @ 2020: This is an open-access article distributed under the terms of the Creative Commons Attribution license which permits unrestricted use, distribution, and reproduction in any medium for non-commercial use (NonCommercial, or CC-BY-NC) provided the original author and source are credited.

Coronavirus outbreak in china acts as a biobomb, which may damage peace, commerce and tour around the globe. It regards as multi-phase risk, since the highly infectious and speedily transmitted of the mortal coronavirus, outbreak occur in country with huge number of population, active commerce and tourism and spread of infection supporter environment through behavior of eating virus animals which carry the virus.

Fortunately much behavior and even believes gives strong protection against the coronavirus, which makes that societies at low risk of coronavirus outbreak, unfortunately that behaviors and believes were uncommon in corona highly infested region.

Many communities believe that meat is forbidden, and they depend on vegetables and fruits as food, such as many people in India. In the other side huge number of population believe that eating of known of carnivores and reptile are not allowing and they depend on other sources of food such as herbivores, such as middle east societies, eating of seven pieces of softening dates (called ajwaa in some societies) will offer protection against poisons produce by coronavirus, then believes orientated nutrition may some protection against the coronavirus. Also, many individuals around the globe are vegetarians and that behavior -orientated nutrition.

New research shows that women have more cells in the olfactory bulb - the area of the brain that is dedicated to sense of smell - than men [1], so they are more exposed to that air transmitted virus, women in certain community cover their faces completely as habit in certain part of the world and as religious value in many societies, and we may name that value orientated clothing.

Hands washing also diminish spread of this fatal pathogen, and in some Middle East communities, people wash their hands at least five times/day, then this healthy behavior offer good control measures.

Politeness also is a nice adjective, so when you wish to cough put your hand on your mouth to prevent spreading of germs to the surroundings.

As antibiotics are not effective to viral infection and the war between viruses and humans still un-balanced, so we need to support psychological protective measures as an easy and potent control method.

I am believed that few words will save millions of people looking for the small piece of wood to hang their wishes, hope and even their souls.

\section{REFERENCES}

1. Catharine Paddock. (2014). Women's finer sense of smell may be due to more brain cells, November 6, 2014.

https://www.medicalnewstoday.com/articles/28499 1. 